Економічні науки: збірник наукових праџь Луцького національного технічного університету. - Серія "Регіональна економіка". - Випуск 15 (59). - Редкол.: відп. ред. д.е.н., професор Л.Л. Ковальська. - Луцьк: ІВВ Луичького НТУ, 2018. - 292 с.

УДК 332.14

Вахович I.М., д.е.н., професор, завідувач кафедри фінансів, банківської справи та страхування

Салівончик I.M., аспірант кафедри фінансів, банківської справи та страхування

Луцький національний технічний університет

\title{
СТРУКТУРНО-МЕТОДОЛОГІЧНІ ДОСЛІДЖЕННЯ МОДЕРНІЗАЦІЇ ЕКОНОМІКИ РЕГІОНУ
}

У статті розглянуто теоретичні аспекти модернізації економіки регіону, охарактеризовано види модернізації економіки за різними класифікаціями.

Ключові слова: модернізація, теорії модернізації регіонального сектору, інтеграція, ЄС.

\section{Vachovych I., Salivonchyk I. \\ STRUCTURAL-METHODOLOGICAL RESEARCH OF ECONOMIC MODERNIZATION OF THE REGION}

Modernisation must not be seen as a simple set of specific programs in various areas of political, economic and social life of the country, although no such programs are technologically difficult to implement the modernization process. Therefore, we consider the modernization as a particular economic ideology, which leads to a large-scale qualitative changes. It is the modernization provides the basis for technological updates suplita, because otherwise the country simply is not a real request for a large-scale innovation. In scientific work "Modernization of Ukraine: defining reform priorities: Draft for discussion", the concept of modernization: “...it is primarily a comprehensive process of reforming existing and establishing new political, legal, economic and social institutions, and the borrowing of cultural norms that meet the highest standards and values of developed democratic countries.

Scientists are considering an upgrade, as a certain ideology around which to build specific reforms that lead to large qualitative changes. And then upgrade provides the conditions for technological development and the need for innovation in various areas. For the regions of Ukraine at the present stage of development three stages of modernization of the economy are grounded; industrial, postindustrial and neo-industrial. In recent years, the Ukrainian industry is mostly oldfashioned enterprises of the Soviet era, where production technologies are lagging behind for decades from modern ones. Therefore, we believe that a new era of industrialization is needed in the country as never before, namely structural modernization and development of the regional economy, because our country, in 
Економічні науки: збірник наукових праиь Луиького національного технічного університету. - Серія "Регіональна економіка". - Випуск 15 (59). - Редкол.: відп. ред. д.е.н., професор Л.Л. Ковальська. - Луцьк: ІВВ Луиького НТУ, 2018. - 292 с.

addition to the leading positions in the agro-industrial sector, can also be an attractive production site for domestic and global enterprises. The modernization of the Ukrainian economy should be aimed at building a highly effective competitive dynamic socially oriented economic system, in which economic development is ensured primarily through expanding the use of innovative technologies, rational use of human potential on the basis of increasing and improving the quality level of export potential and integration into global economic relations, expansion of capacity and balance of the domestic market. In other words, we are talking about restructuring the economy on a fundamentally new principles of management. Today, the economic aspect of the region's European integration represented first and foremost, the economic and monetary Union (EMU), which represents the intertwining of monetary policy with economic policy and involves the harmonization (convergence) of economic and monetary policies of member countries Union with the aim of introducing a single currency - the Euro. To integrate into the EU, regions need to substantially change the process of implementing economic and financial policies. You need to change the tools for regulating the foreign exchange market and create conditions for the merger of our financial market with globalized world, but in practice, this can radically change the financial services market in the country and especially the banking system. All of this requires, in our view, fundamental research.

Key words: modernization, theories of modernization of the regional sector, integration, EU.

\section{Вахович И.Н., Саливончик И.Н. СТРУКТУРНО-МЕТОДОЛОГИЧЕСКИЕ ИССЛЕДОВАНИЯ МОДЕРНИЗАЦИИ ЭКОНОМИКИ РЕГИОНА}

В статье рассмотрены теоретические аспекты модернизации экономики региона, охарактеризованы виды модернизации экономики по разным классификациям.

Ключевые слова: модернизация, теории модернизации регионального сектора, интеграция, ЕС.

Постановка проблеми у загальному вигляді та ї̈ зв'язок 3 важливими науковими та практичними завданнями. Нині перед регіонами України актуальною стала проблема здійснення ефективних структурних перетворень, зокрема модернізації економіки у процесі інтеграції в європейський економічний простір. Основним новітнім шляхом 
Економічні науки: збірник наукових праиь Луиького національного технічного університету. - Серія "Регіональна економіка". - Випуск 15 (59). - Редкол.: відп. ред. д.е.н., професор Л.Л. Ковальська. - Луцьк: ІВВ Луцького НТУ, 2018. - 292 с.

таких змін $є$ забезпечення економічного розвитку з врахуванням нових викликів глобального середовища. Однак системна ефективна модернізація повинна спиратися на чітко сформовану теоретико-методологічну платформу, розробкою якої сьогодні займаються науковці. Тому визначення сутності модернізації у контексті економічних категорій має важливе значення для обгрунтування вагомості іiі введення та виявлення реальних переваг.

Аналіз останніх досліджень, у яких започатковано вирішення проблеми. Щодо дослідження сутності та значення модернізаціії у сучасній економічній науці можна віднести саме таких вітчизняних дослідників-економістів як: Амосов О., Бураковський І., Валінкевич Н., Качала Т., Коліушко I., Мамалуй О., Матковський П., Михальченко М., Петрович Й., Мочерний С.В, Федулова Л.І., Й.М. Петрович, М.М. Салун, М.Т Пашута, О.М. Шкільнюк. Вагомий внесок у дослідження питань модернізації зробили також сучасні зарубіжні вчені: Ф. Агійон, С.С. Дьомін, С.А. Ковальчук, В.А. Лаврентьєв, П. Хоуітт. Питаннями еволюції теорії модернізації займаються Балджи М., Бужимська К., Гедз М. Хоуітт П., Агійон Ф., та інші.

Цілі статті. Основна мета дослідженняя полягає в обгрунтуванні структурно-методологічних аспектів модернізації економіки регіону.

Виклад основного матеріалу дослідження, 3 повним обгрунтуванням отриманих наукових результатів. Термін «модернізація» у перекладі 3 англійського «modernisation» означає «осучаснення», удосконалення, надання будь-чому сучасного вигляду, переробка відповідно до сучасних вимог [1]. Зародження поняття та основні ідеї модернізації були закладені в XVI ст. і 3 того часу тривають дискусії щодо змісту модернізації, що дало можливість виділити 4 загальні етапи розвитку модернізації, а саме: рання індустріальна (мануфактурна) модернізація (XVI ст. - середина XVIII ст.); індустріальна модернізація (кін. XVIII ст. - середина XIX ст.); пізня індустріальна модернізація (I пол. $\mathrm{XX}$ ст.); постіндустріальна модернізація (сер. XX ст. - дотепер). Теорія 
Економічні науки: збірник наукових праџь Луцького національного технічного університету. - Серія "Регіональна економіка". - Випуск 15 (59). - Редкол.: відп. ред. д.е.н., професор Л.Л. Ковальська. - Луцьк: ІВВ Луцького НТУ, 2018. - 292 с.

\section{модернізації була сформована в середині XX ст. і вже пройшла декілька етапів еволюції (таблиці 1.).}

\section{Таблиця 1}

\section{Етапи еволюції теорії модернізації}

\begin{tabular}{|c|c|}
\hline Назва періоду / часові межі / & Коротка характеристика \\
\hline $\begin{array}{c}\text { представники } \\
\text { періоду народження та } \\
\text { стрімкого росту дослідження } \\
\text { модернізаційних процесів в } \\
\text { класичній версії / друга } \\
\text { половина 1950-х - перша } \\
\text { половина 1960-х рр./ } \\
\text { критичний період / кінець } \\
\text { 1960-х - 1970-ті pp./ } \\
\text { Валерстайн I. }\end{array}$ & $\begin{array}{l}\text { Модернізація розглядалася як єдиний глобальний } \\
\text { процес переходу суспільств від традиційності } \\
\text { (недостатнього розвитку) до сучасності на основі } \\
\text { розповсюдження існуючих ідей і технологій } \\
\text { європейського центру по всьому світу. Представники } \\
\text { класичної теорії модернізму вважали, що перехід від } \\
\text { традиційності до сучасності зумовлює зміни у всіх } \\
\text { сферах життя. Труднощі реалізації теорії модернізації } \\
\text { країнами третього світу, оскільки країни не завжди } \\
\text { мали у розпорядженні необхідні ресурси. Суспільна } \\
\text { критика дала поштовх представникам і прихильникам } \\
\text { теорії модернізму усунути некоректні теоретичні } \\
\text { складові модернізаційної течії та вдосконалити їх. }\end{array}$ \\
\hline $\begin{array}{c}\text { посткритичний період / } \\
\text { 1980-х pp. / Соу Е., } \\
\text { Хантінгтон С. }\end{array}$ & $\begin{array}{l}\text { Представники школи модернізації в відмовились } \\
\text { розглядати модернізацію як рух до західних } \\
\text { iнституцій і прийшли до висновку, що країна може } \\
\text { розвиватись, вибравши власний, оригінальний, } \\
\text { шлях на основі національних моделей модернізації } 3 \\
\text { врахуванням національних традицій. }\end{array}$ \\
\hline $\begin{array}{l}\text { період неомодернізаційного } \\
\text { та постмодернізаційного } \\
\text { аналізу / кінець 1980-х - } \\
\text { 1990-х рр./ Тіріакян Е., } \\
\text { Штомпка П., Цапф В., Бек У. }\end{array}$ & $\begin{array}{l}\text { Становлення неомодернізаційного } \\
\text { постмодернізаційного ало аналізу зумовлено } \\
\text { грандіозними трансформаціями у країнах Центрально- } \\
\text { Східної Європи та Євразії. Основні теоретичні } \\
\text { положення даного етапу: відмова від розуміння } \\
\text { модернізації як руху в сторону західних цінностей, } \\
\text { визнання можливості власних оригінальних ідей } \\
\text { розвитку; визнання позитивної ролі традицій при } \\
\text { здійсненні модернізаційних перетворень; роль та } \\
\text { вплив зовнішнього фактору на модернізацію; відхід } \\
\text { від еволюціоністського телеологізму; чинник історії; } \\
\text { відмова від трактування модернізації як єдиного } \\
\text { процесу системної трансформації; циклічність } \\
\text { природи модернізації. }\end{array}$ \\
\hline сучасний етап / Амосов О. Ю. & $\begin{array}{l}\text { Стрімка зміна стадій росту на макрорівні (системній } \\
\text { кризі передує соціально-економічна сталість у } \\
\text { більшості економічно розвинених країн, а подолання } \\
\text { кризи супроводжується загостренням суперечностей } \\
\text { у суспільстві, збільшенням соціальних } \\
\text { трансформацій, зміною конфігурації суспільних } \\
\text { матриць), що відповідає постмодернізаційному } \\
\text { аналізу в посткризовий період. }\end{array}$ \\
\hline
\end{tabular}

Джерело [2,3,4] 
Економічні науки: збірник наукових праџь Луцького національного технічного університету. - Серія "Регіональна економіка". - Випуск 15 (59). - Редкол.: відп. ред. д.е.н., професор Л.Л. Ковальська. - Луцьк: ІВВ Луиького НТУ, 2018. - 292 с.

Саме під впливом еволюції теорії модернізації, досліджувана категорія трактується по-різному.

Зауважимо, що модернізація є однією 3 необхідних умов становлення нового світового порядку. В iї основі лежить визнання головною закономірністю соціального розвитку регіону постійної зміни, ускладнення політичних, економічних і культурних структур та їхніх функцій відповідно до потреб раціонального та ефективного функціонування суспільства.

За словами, П. Хоуітта та Ф. Агійона, які створили так звану формальну теорію шумпетерівського економічного зростання, згідно якій у країнах, що за рівнем продуктивності праці далеко відстають від передових технологічних держав, доцільно займатися модернізацією, а в країнах, які знаходяться близько до переднього технічного прогресу, доцільно займатися інноваціями.

На нашу думку, в цілому немає сенсу надавати більшу перевагу модернізації чи інноваціям в економіці, оскільки $є$ високотехнологічні та наукоємні галузі, які вже займаються інноваціями, а деяким у першу чергу необхідна модернізація. Таким чином, шлях побудови інноваційної економіки, на наш погляд, полягає у створенні умов i механізмів як для модернізації, так і для інновацій. Інша річ, коли постає питання вибору шляху розвитку певної галузі економіки, наприклад, переробної галузі промисловості. Ця галузь не відноситься до групи високотехнологічних та наукомістких. Але на сьогоднішній день ऑiі техніко-технологічний стан потребує негайного оновлення. Тому шлях іï розвитку, вважаємо, полягає у створенні умов для ефективної широкомасштабної модернізації.

Ми виходимо 3 того, що всі наявні та можливі успіхи технологічної модернізації, модернізуюче переобладнання промислових виробництв країни, є й може бути лише наслідком проведення комплексних інституційних реформ.

Оскільки модернізація є достатньо складним та доволі витратним процесом, який здійснюється сьогодні в умовах недостатності фінансових коштів, це потребує його щільного планування - як стратегічного, так і тактичного.

Саме у процесі планування модернізації здійснюється відбір тих технологій та технологічного устаткування, що 
Економічні науки: збірник наукових праџь Луцького національного технічного університету. - Серія "Регіональна економіка". - Випуск 15 (59). - Редкол.: відп. ред. д.е.н., професор Л.Л. Ковальська. - Луцьк: ІВВ Луиького НТУ, 2018. - 292 с.

відповідають умовам зовнішнього середовища, дозволяють отримати інституціональні переваги та можуть бути освоєні економічним суб' єктом з урахуванням наявних у нього ресурсів або з урахуванням доступу до ресурсів.

У зв'язку 3 вищевикладеним процес планування модернізації промислового підприємства уявляє собою послідовність дій, що забезпечують здійснення певного виду модернізації підприємства. Він включає визначення цілі модернізації, аналіз, організацію, реалізацію та регулювання процесу модернізації. Також підприємствам необхідна глибока, системна модернізація (яка може бути класифікована за видами, напрямами, предметом), наслідком проведення якої $\epsilon$ нарощування сукупного потенціалу підприємства для підвищення його конкурентоспроможності та випуску інноваційної продукції таблиці 2.

Таблиця 2

Види модернізації економіки за різними

класифікаційними ознаками

\begin{tabular}{|c|c|}
\hline Модернізація & $\begin{array}{c}\text { Характеристика за класифікаційними } \\
\text { ознаками }\end{array}$ \\
\hline \multicolumn{2}{|r|}{ За видами } \\
\hline Економічна & $\begin{array}{lr}\text { Спрямована на досягнення } & \text { економічного } \\
\text { ефекту від впровадження нових технологій, } \\
\text { ресурсоощадливість, } & \text { підвищення } \\
\text { продуктивності праці. } & \\
\end{array}$ \\
\hline Соціальна & $\begin{array}{l}\text { Сприяе розвитку персоналу підприємства, } \\
\text { поліпшенню умов праці, соціальних пакетів, } \\
\text { організаційної культури та соціальної } \\
\text { відповідальності бізнесу перед власними } \\
\text { працівниками та оточуючим середовищем. } \\
\text { Наприклад, розробка спеціальних соціальних } \\
\text { компенсаційних пакетів за шкідливих умов } \\
\text { праці, понаднормову роботу тощо. }\end{array}$ \\
\hline Екологічна & 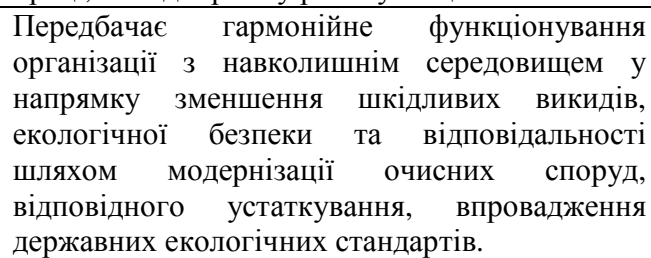 \\
\hline
\end{tabular}


Економічні науки: збірник наукових праџь Луцького національного технічного університету. - Серія "Регіональна економіка". - Випуск 15 (59). - Редкол.: відп. ред. д.е.н., професор Л.Л. Ковальська. - Луиьк: ІВВ Луиького НТУ, 2018. - 292 с.

Продовження таблиці 2

\begin{tabular}{|c|c|}
\hline 1 & 2 \\
\hline \multicolumn{2}{|r|}{ За предметом } \\
\hline Модернізація якості & 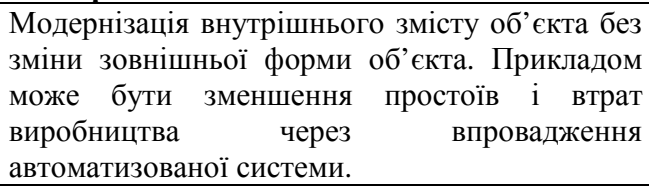 \\
\hline Модернізація форми & $\begin{array}{l}\text { Модернізація зовнішніх, видимих ознак без } \\
\text { зміни внутрішнього змісту об'єкта }\end{array}$ \\
\hline Змішана модернізація & $\begin{array}{l}\text { Модернізація зовнішніх і внутрішніх ознак } \\
\text { об'єкта, що приводить до зміни його форми і } \\
\text { якості. Наприклад, запуск нової лінії для } \\
\text { випуску нової продукції. Така модернізація є } \\
\text { найпоширенішою, адже із зміною зовнішніх } \\
\text { ознак, найчастіше і покращуються внутрішні } \\
\text { характеристики, якість продукції чи процесу. }\end{array}$ \\
\hline \multicolumn{2}{|r|}{ За напрямами } \\
\hline Організаційно економічна & 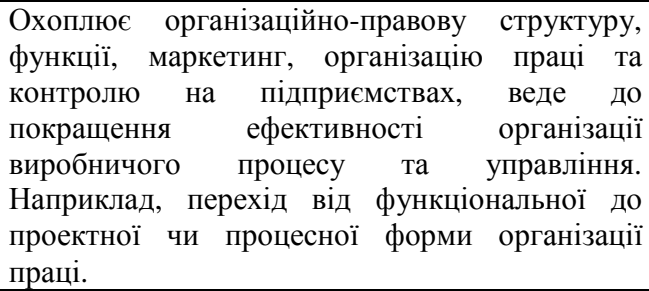 \\
\hline Техніко-технологічна & $\begin{array}{l}\text { Спрямована на оновлення матеріально- } \\
\text { технічної бази, технології, техніки шляхом } \\
\text { запозичення новітніх світових практик чи } \\
\text { власних інноваційних розробок для } \\
\text { можливості випуску } \\
\text { високонкурентоспроможної продукції. }\end{array}$ \\
\hline Інноваційна & $\begin{array}{l}\text { Комплекс заходів для підготовки організації } \\
\text { до можливості формування та реалізації } \\
\text { стратегії інноваційного розвитку. Наприклад, } \\
\text { створення в організаційній структурі відділу } \\
\text { інноваційного розвитку організації. }\end{array}$ \\
\hline
\end{tabular}

На сучасному етапі розвитку стає очевидним необхідність модернізації економіки регіону, адже саме зараз регіони нашої країни знаходяться у пошуках свого місця в територіальній 
Економічні науки: збірник наукових праиь Луиького національного технічного університету. - Серія "Регіональна економіка". - Випуск 15 (59). - Редкол.: відп. ред. д.е.н., професор Л.Л. Ковальська. - Луцьк: ІВВ Луцького НТУ, 2018. - 292 с.

системі країни i роблять спробу побудувати ефективний механізм управління відтворювальними процесами, що протікають на їх території. Якщо розглядати регіони як різні географічні частини країни, то регіональна модернізація $€$ однією зі складових модернізації.

За словами зарубіжних науковців можна виділити такі теорії модернізації регіонального простору, а саме:

теорія регіональної економічної модернізації, теорія регіональної соціальної модернізації, теорія регіональної політичної модернізації, теорія правової модернізації.

Однак ми робимо акцент дослідження саме на регіональну структурну модернізацію економічної складової, адже стале економічне зростання економіки - це саме те, що ми прагнемо бачити. За останні роки наша держава розпочала впровадження перших серйозних кроків на шляху інтеграції до Свропейського Союзу. Наші регіони України стали учасниками торговельних відносин після Угоди про зону вільної торгівлі, але відсоткове значення експорту та імпорту областей різниться.[10]

Зазначимо, що регіональні процеси, що відбуваються в межах Європейського співтовариства, принципово відрізняються від подібних в інших інтеграційних формуваннях. Причиною цього стала Хартія регіоналізму, яка була ухвалена Європарламентом у 1988 році. Згідно з цим документом регіон визначається як гомогенний простір, що має етнічну, культурну, фізико-географічну, мовну спільність, а також спільність господарських структур та спільну історичну долю. [11].

Також 3 метою забезпечення сталого економічного розвитку України Верховною Радою було прийнято низку промислово-економічних законопроектів, зокрема: про державно-приватне партнерство; індустріальні парки; про енергосервісні контракти (ЕСКО) - масштабну енергомодернізацію; створення експортнокредитного агентства, та інших.

Сьогодні економічний аспект регіону європейської інтеграції представлений, у першу чергу, економічним i 
Економічні науки: збірник наукових праць Луиького національного технічного університету. - Серія "Регіональна економіка". - Випуск 15 (59). - Редкол.: відп. ред. д.е.н., професор Л.Л. Ковальська. - Луиьк: ІВВ Луиького НТУ, 2018. - 292 с.

валютним союзом (ЕВС), що уособлює тісне переплетіння грошово-кредитної політики 3 економічною політикою i передбачає гармонізацію (конвергенцію) економічної та монетарної політики країн - членів Союзу 3 метою запровадження єдиної валюти - євро. Таким чином європейська інтеграція для регіонів України без сумніву це шлях модернізації економіки, подолання технологічної відсталості, залучення іноземних інвестицій і новітніх технологій, створення нових робочих місць, підвищення конкурентоспроможності вітчизняного товаровиробника, вихід на світові ринки, насамперед на ринок ЄС. Як невід'ємна частина Європи, Україна орієнтується на діючу в провідних європейських країнах модель соціально-економічного розвитку.

Висновки. Отже, щоб інтегруватись у $\mathrm{CC}$, регіонам необхідно суттєво змінити процес реалізації економічної та фінансової політики. Необхідно змінити інструментарій регулювання валютного ринку та створити умови для злиття нашого фінансового ринку з глобалізованим світовим, але на практиці це може докорінно змінити ринок фінансових послуг у країні й особливо - банківську систему. Все це вимагає, на нашу думку, грунтовних наукових досліджень.

1. Эйзенштадт Ш. Новая парадигма модернизации. Распад ранней парадигмы модернизации и пересмотр соотношения между традицией и современностью: хрестоматия: учеб. пособие для студентов, ред. и автор вступ. ст. Б.С. Ерасов. М.: Аспект Пресс. (1998a) 556 с. С. 470-479.

2. Амосов О.Ю., Гавкалова Н.Л. Модернізація в Україні: шлях в майбутнє [Електронний ресурс]. - Режим доступу: jrnl.nau.edu.ua/index.php/SR/article/download/4383/4515.

3. Гедз М.Й. Економічний простір. Еволюиія розвитку теорії модернізаиіï - 2014. - № 88. - С. 28-38.

4. Побережников И.В. Теория модернизации: основные этапы эволюции Екатеринбург: Волот, 2001. - Вып. 4: Евразийское пограничье. C. $217-246$.

5. Бужимська К.О. Деякі складові теоретико-методологічної бази інноваційно-технологічної модернізації. 2009. - № 4. - С. 202-207.

6. Бужимська К.О. Модернізація економіки: технологічно-структурний. 2009. - № 3(49). - C. 214-217. 
Економічні науки: збірник наукових праць Луиького національного технічного університету. - Серія "Регіональна економіка". - Випуск 15 (59). - Редкол.: відп. ред. д.е.н., професор Л.Л. Ковальська. - Луцьк: ІВВ Луцького НТУ, 2018. - 292 с.

7. Валінкевич Н.В. Вісник Чернівецького торговельно-економічного інституту Управління потенціалом та розвитком підприємств на основі модернізаиії. Чернівці 2012. - №1(45). - С. 128-134.

8. Вардомский Л.Б., Шурубович А.В. Модернизация экономики в станах СНГ: типы, ресурсы, инструменты Економіка і прогнозування. - 2009. №1. - C. 70-77.

9. Салун М.М. Всеукраїнський науково-виробничий журнал. Фактори модернізації промислового ресурсного потенщуіалу. 2012. - №4(30). - С. 49 - 51.

10. Яка область стала лідером в Україні з експорту товарів до ЄС. [Електронний ресурс]. - Режим доступу:https://agropolit.com/news/6222-yakaoblast-stala-liderom-v-ukrayini-z-eksportu-tovariv-do-yes

11. Романюк А.: Видавничий центр ЛНУ імені Івана Франка. Порівняльний аналіз політичних інститутів країн Західної Європи: Монографія. Львів, 2007. - 391 с. 